\title{
Adjunctive corticosteroids for Pneumocystis jiroveci pneumonia in patients with HIV infection: a meta-analysis of randomised controlled trials
}

\author{
Matthias Briel*1, Remy Boscacci ${ }^{2}$, Hansjakob Furrer ${ }^{2}$ and Heiner C Bucher ${ }^{1,3}$
}

Address: ${ }^{1}$ Institut für klinische Epidemiologie, Universitätsspital Basel, 4031 Basel, Switzerland, ${ }^{2}$ Klinik und Poliklinik für Infektiologie, Inselspital, 3010 Bern, Switzerland and ${ }^{3}$ Klinik für Infektiologie, Universitätsspital Basel, 4031 Basel, Switzerland

Email: Matthias Briel* - brielm@uhbs.ch; Remy Boscacci - remy.boscacci@insel.ch; Hansjakob Furrer - hansjakob.furrer@insel.ch; Heiner C Bucher - hbucher@uhbs.ch

* Corresponding author

Published: 07 November 2005

BMC Infectious Diseases 2005, 5:101 doi:10.1186/147I-2334-5-101
Received: 27 June 2005

Accepted: 07 November 2005

This article is available from: http://www.biomedcentral.com/I47I-2334/5/I0I

(c) 2005 Briel et al; licensee BioMed Central Ltd.

This is an Open Access article distributed under the terms of the Creative Commons Attribution License (http://creativecommons.org/licenses/by/2.0), which permits unrestricted use, distribution, and reproduction in any medium, provided the original work is properly cited.

\begin{abstract}
Background: The objective of this study was to review the effects of adjunctive corticosteroids on overall mortality and the need for mechanical ventilation in HIV-infected patients with Pneumocystis jiroveci pneumonia (PCP) and substantial hypoxemia (arterial oxygen partial pressure $<70 \mathrm{mmHg}$ or alveolar-arterial gradient $>35 \mathrm{mmHg}$ on room air).

Methods: We conducted a systematic search of the literature for randomised trials published up to December 2004. Selected trials compared adjunctive corticosteroids with placebo or usual care in HIV-infected patients with PCP and reported mortality data. Two teams of reviewers independently evaluated the methodology and extracted data from each primary study.

Results: Six studies were included in the meta-analysis. Risk ratios for overall mortality for adjunctive corticosteroids were $0.54(95 \%$ confidence interval $[\mathrm{Cl}], 0.38-0.79)$ at I month and 0.67 $(95 \% \mathrm{Cl}, 0.49-0.93)$ at 3-4 months of follow-up. Numbers needed to treat, to prevent I death, are 9 patients in a setting without highly active antiretroviral therapy (HAART) available and 22 patients with HAART available. Only the 3 largest trials provided data on the need for mechanical ventilation with a risk ratio of $0.37(95 \% \mathrm{Cl}, 0.20-0.70)$ in favour of adjunctive corticosteroids.
\end{abstract}

Conclusion: The number and size of trials investigating adjunctive corticosteroids for HIVinfected patients with PCP is small, but our results suggest a beneficial effect for patients with substantial hypoxemia.

\section{Background}

With the introduction of highly active antiretroviral therapy (HAART) more than a decade ago, the incidence of Pneumocystis jiroveci pneumonia (PCP) [1] has decreased significantly in the Western hemisphere. However, PCP still remains the most common opportunistic infection in patients infected with the human immunodeficiency virus
(HIV) [2]. Among patients with HIV infection and PCP the mortality rate is 10 to $20 \%$ during the initial infection and increases substantially with the need for mechanical ventilation [3]. In 1990 an expert panel recommended the use of corticosteroids for HIV-infected patients with PCP and substantial hypoxemia (initial arterial oxygen partial pressure of $<70 \mathrm{mmHg}$ or alveolar-arterial gradient $>35$ 


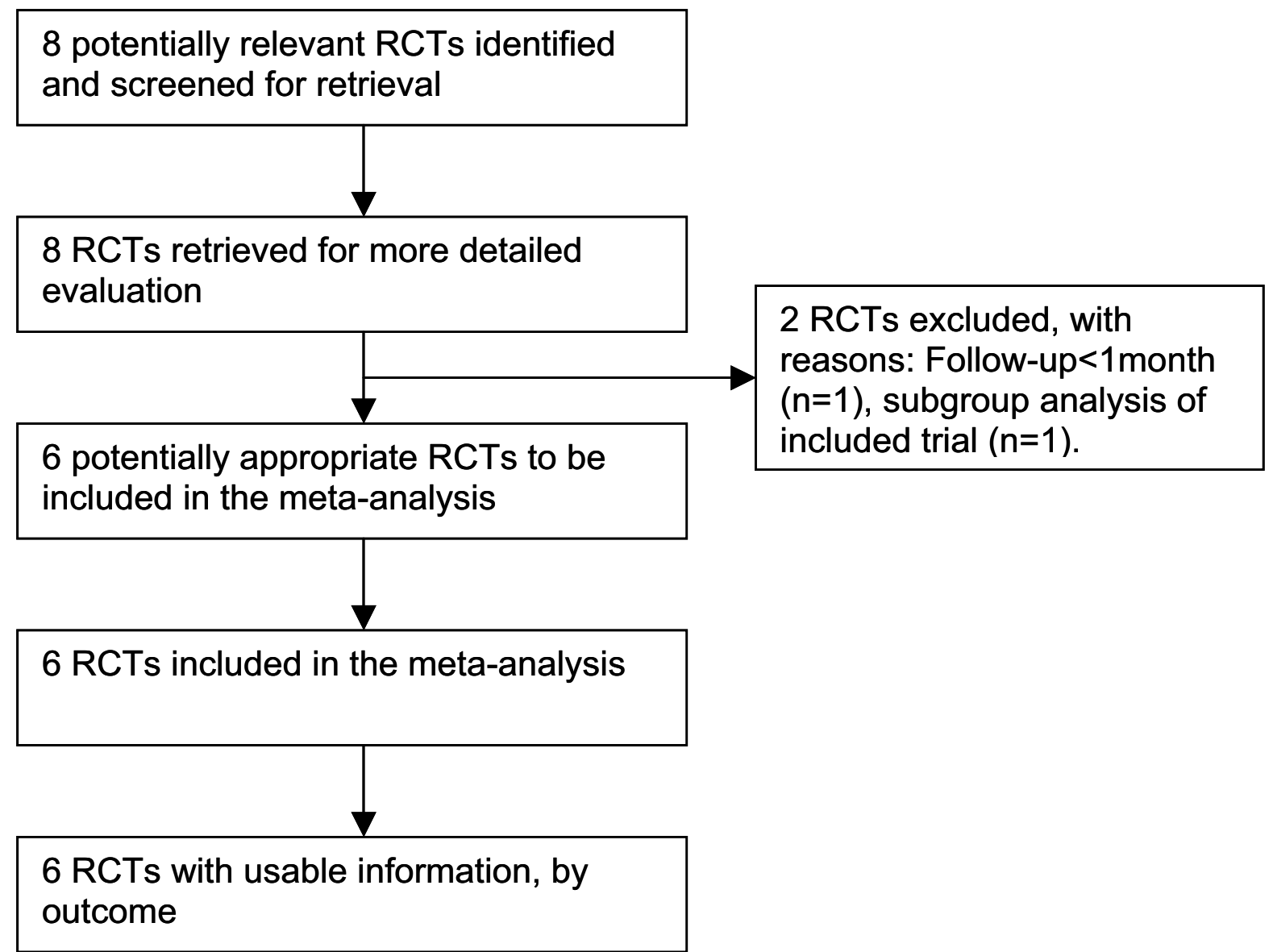

Figure I

Flow diagram of trials. RCT, randomised controlled trial.

mmHg on room air) based on the evidence from five randomised controlled trials [4]. This consensus statement still represents the basis of current treatment guidelines [5]. However, at the time this statement was made, one trial was not yet completed [6], two trials were stopped prematurely $[7,8]$, and one trial was not published in full [9]. In 1992 a systematic review qualitatively summarised the same incomplete data [10].

We present an updated systematic review and meta-analysis of randomised controlled trials to assess the magnitude of effects of adjunctive corticosteroid therapy on overall mortality and the need for mechanical ventilation in HIVrelated PCP. In addition, we provide numbers needed to treat that may serve as estimates for the expected benefit of adjunctive corticosteroid therapy in the presence and absence of HAART.

\section{Methods}

\section{Search for relevant studies}

We searched MEDLINE (January 1985 - December 2004), EMBASE (January 1985 - December 2004) and the Cochrane Library (issue 4, 2004) without language restrictions to identify randomised controlled trials that compared adjunctive corticosteroids to control in HIVinfected patients with PCP. We used the terms steroid*, corticosteroid*, glucocorticoid*, pneumocystis, PCP, *carinii, *jiroveci as text words and Glucocorticoids, Adrenal Cortex Hormones, Steroids, Pneumocystis Infections, Pneumocystis jiroveci, and Pneumonia, Pneumocystis as Medical Subject Headings. We restricted the search to articles indexed as randomised controlled trials (publication type) or drug therapy (subject heading) or those that included the words random* or placebo in their titles or abstracts. We further reviewed the reference 


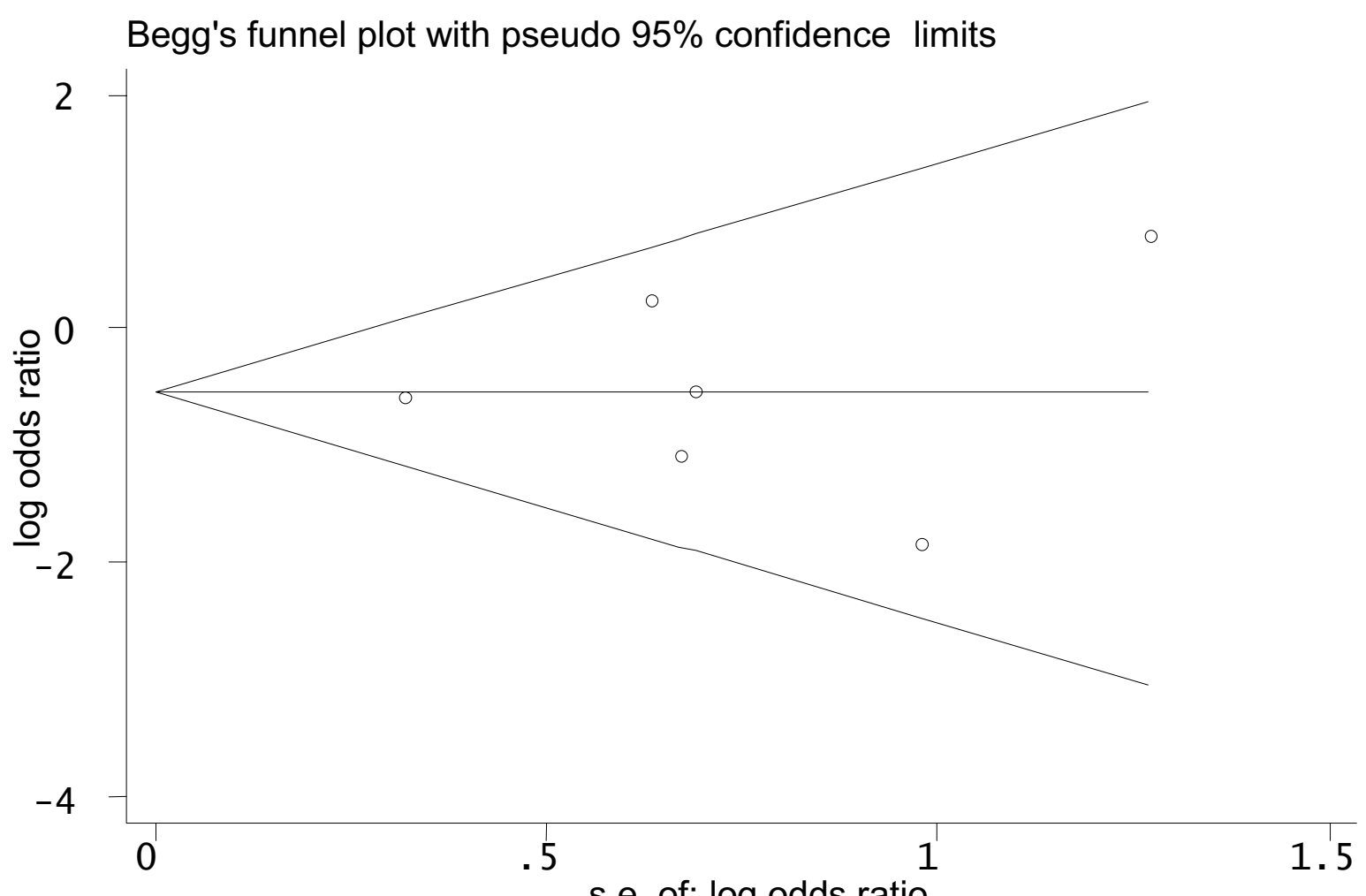

Figure 2

Funnel plot to evaluate the presence of a publication bias in trials investigating adjunctive corticosteroids for pneumocystis jiroveci pneumonia in HIV-infected patients. The funnel graph plots the log of the treatment odds ratio against the standard error (s.e.) of the log odds ratio (an indicator of sample size). Open circles represent trials included in the meta-analysis. The line in the centre indicates the summary log odds ratio. In the absence of a publication bias, the log odds ratio estimates from smaller trials are expected to be scattered above and below the summary estimate, producing a symmetric triangular or funnel shape. When smaller trials with larger log odds ratios are missing, the funnel plot appears asymmetric and may indicate the presence of a publication bias. In our systematic review the funnel plot looks symmetric. The Egger test for publication bias was not statistically significant $(P=0.9 \mathrm{I})$.

lists from previously published overviews [4,10], we searched UptoDate version 2005 and Clinical Evidence Concise (issue 12, 2004), contacted experts of the field, and searched reference lists of identified publications for citations of additional relevant articles.

\section{Study selection and data abstraction}

Trials were considered eligible for this meta-analysis if they compared corticosteroids to placebo or usual care in HIV-infected patients with PCP in addition to baseline treatment with trimethoprim-sulfamethoxazole, pentamidine or dapsone-trimethoprim, used random allocation, and reported mortality data. We excluded trials in patients with no or mild hypoxemia (arterial oxygen partial pressure $>70 \mathrm{mmHg}$ or an alveolar-arterial gradient $<35 \mathrm{mmHg}$ on room air) and trials with a follow-up of less than 30 days.

Two teams of investigators (MB/HCB and $\mathrm{RB} / \mathrm{HF}$ ) assessed study eligibility and quality blinded to one another's rating and resolved any disagreement by consensus. Data of eligible trials were abstracted in duplicate. We assessed the quality of included trials with respect to concealment of treatment allocation; blinding of patients, caregivers or assessors of clinical outcomes; performance of a sample size calculation; and if the trial was stopped 
Table I: Characteristics of included trials

\begin{tabular}{|c|c|c|c|c|c|c|c|c|c|c|}
\hline $\begin{array}{l}\text { Author } \\
\text { (year) } \\
\text { reference }\end{array}$ & $\begin{array}{l}\text { Diagnosis of } \\
\text { PCP }\end{array}$ & $\begin{array}{l}\text { Baseline } \\
\text { treatment } \\
\text { for PCP }\end{array}$ & $\begin{array}{l}\text { Oxygenation } \\
\text { entry criteria }\end{array}$ & $\begin{array}{l}\text { Corticoid } \\
\text { (route)/initial } \\
\text { daily dose/ } \\
\text { duration } \\
\text { (days) }\end{array}$ & $\begin{array}{l}\text { Interval } \\
(\max .) *\end{array}$ & $\begin{array}{l}\text { Blinding } \\
\text { patients/care } \\
\text { givers/ } \\
\text { assessors }\end{array}$ & $\begin{array}{l}\text { Concealed } \\
\text { allocation/n } \\
\text { centres }\end{array}$ & $\begin{array}{l}\text { Sample size } \\
\text { calculation/ } \\
\text { stopped early }\end{array}$ & $\begin{array}{l}\text { Randomised } \\
\text { individuals to } \\
\text { I/C }\end{array}$ & $\begin{array}{l}\text { Total deaths } \\
\text { in I/C }\end{array}$ \\
\hline $\begin{array}{l}\text { Clement et al. } \\
\text { (1989) [9] }\end{array}$ & BAL, sputum & $\begin{array}{l}88 \% \text { TMP-SMX, } \\
12 \% \\
\text { Pentamidine }\end{array}$ & $\begin{array}{l}\mathrm{PaO}_{2}<5 \mathrm{I} \\
\mathrm{mmHg} \text { (room } \\
\text { air) }\end{array}$ & $\begin{array}{l}\text { Methylpredniso } \\
\text { lon (IV)/240 } \\
\mathrm{mg} / 8 \mathrm{~d}\end{array}$ & Unlimited & $\begin{array}{l}\text { Yes/Yes/ } \\
\text { Unclear }\end{array}$ & Unclear/I & Unclear/No & $19 / 22$ & $9 / 9$ at 56 days \\
\hline $\begin{array}{l}\text { Montaner et al. } \\
\text { (1990) [8] }\end{array}$ & BAL & $\begin{array}{l}\text { TMP-SMX, } \\
\text { Pentamidine, } \\
\text { Dapsone-TMP }\end{array}$ & $\begin{array}{l}85-90 \% \mathrm{O}_{2-}^{-} \\
\text {Saturation } \dagger\end{array}$ & $\begin{array}{l}\text { Prednisone } \\
\text { (oral) } / 60 \mathrm{mg} / 7 \\
\mathrm{~d} \text { with } 14 \mathrm{~d} \\
\text { tapering }\end{array}$ & $48 \mathrm{~h}$ & $\begin{array}{l}\text { Yes/Yes/ } \\
\text { Unclear }\end{array}$ & Yes/I & Yes/Yes & $18 / 19$ & $\begin{array}{l}1 / 0 \text { at } 30 \text { days } \\
2 / 1 \text { at } 90 \text { days }\end{array}$ \\
\hline $\begin{array}{l}\text { Bozzette et al. } \\
(1990) \text { [16] }\end{array}$ & $\begin{array}{l}75 \% \text { BAL, } 15 \% \\
\text { sputum + } \\
\text { presumed }\end{array}$ & $\begin{array}{l}80 \% \text { TMP-SMX, } \\
\text { I8\% } \\
\text { Pentamidine, } \\
2 \% \text { Dapsone- } \\
\text { TMP }\end{array}$ & $\begin{array}{l}\text { Hypoxemia } \\
\text { ratio }>75 \ddagger\end{array}$ & $\begin{array}{l}\text { Prednisone } \\
\text { (oral) } / 80 \mathrm{mg} / 2 \mathrm{l} \\
\mathrm{d} \text { or as baseline } \\
\text { treatment }\end{array}$ & $36 \mathrm{~h}$ & No/No/Unclear & Yes/6 & Yes/No & $123 / 128$ & $\begin{array}{l}\mid 3 / 28 \text { at } 3 \mid \\
\text { days } 20 / 33 \text { at } \\
84 \text { days }\end{array}$ \\
\hline $\begin{array}{l}\text { Gagnon et al. } \\
\text { (1990) [7] }\end{array}$ & $\begin{array}{l}\text { BAL, biopsy, } \\
\text { sputum }\end{array}$ & TMP-SMX & $\begin{array}{l}\mathrm{PaO}_{2}<75 \\
\mathrm{mmHg}(35 \% \\
\text { oxygen) }\end{array}$ & $\begin{array}{l}\text { Methylpredniso } \\
\text { lon (IV)/I60 } \\
\mathrm{mg} / 7-10 \mathrm{~d}\end{array}$ & $72 \mathrm{~h}$ & $\begin{array}{l}\text { Yes/Yes/ } \\
\text { Unclear }\end{array}$ & Unclear/I & Yes/Yes & $12 / 1 \mid$ & $\begin{array}{l}3 / 9 \text { at } 28 \text { days } \\
5 / 9 \text { at } 120 \text { days }\end{array}$ \\
\hline $\begin{array}{l}\text { Nielsen et al. } \\
\text { (1992) [6] }\end{array}$ & BAL, biopsy & TMP-SMX & $\begin{array}{l}\mathrm{PaO}_{2}<67.5 \\
\mathrm{mmHg} \text { (room } \\
\text { air) }\end{array}$ & $\begin{array}{l}\text { Methylpredniso } \\
\text { lon }(\mathrm{IV}) / 2 \mathrm{mg} / \\
\mathrm{kg} / 10 \mathrm{~d}\end{array}$ & $24 \mathrm{~h}$ & No/No/Unclear & Unclear/3 & Unclear/Yes & $30 / 29$ & $\begin{array}{l}2 / 9 \text { at } 34 \text { days } \\
4 / 9 \text { at } 90 \text { days }\end{array}$ \\
\hline $\begin{array}{l}\text { Walmsley et al. } \\
\text { (1995) [19] }\end{array}$ & $\begin{array}{l}\text { BAL, biopsy, } \\
\text { sputum }\end{array}$ & $\begin{array}{l}82 \% \text { TMP-SMX, } \\
\text { I7\% } \\
\text { Pentamidine, } \\
\text { I\% Dapsone- } \\
\text { TMP }\end{array}$ & $\begin{array}{l}\mathrm{PaO}_{2}<70 \\
\mathrm{mmHg} \text { (room } \\
\text { air) } \S\end{array}$ & $\begin{array}{l}\text { Methylpredniso } \\
\text { lon (IV)/80 mg/ } \\
10 \mathrm{~d}\end{array}$ & $24 \mathrm{~h}$ & $\begin{array}{l}\text { Yes/Yes/ } \\
\text { Unclear }\end{array}$ & Yes/3 & Yes/No & $40 / 38$ & $4 / 6$ at 35 days \\
\hline
\end{tabular}

Abbreviations: PCP, Pneumocystis jiroveci pneumonia; n, number; I/C, intervention/control group; BAL, bronchoalveolar lavage; TMP, trimethoprim; SMX, sulfamethoxazole; IV, intravenous. * Maximal interval between initiation of baseline treatment for Pneumocystis jiroveci pneumonia and initiation of corticosteroid. † Or $5 \%$ decrease on exercise.

$\ddagger \mathrm{PaO}_{2}$ divided by fraction of inspired oxygen.

$\S$ Or alveolar-arterial oxygen gradient $>40 \mathrm{mmHg}$ if arterial blood gases could not be assessed on room air. 


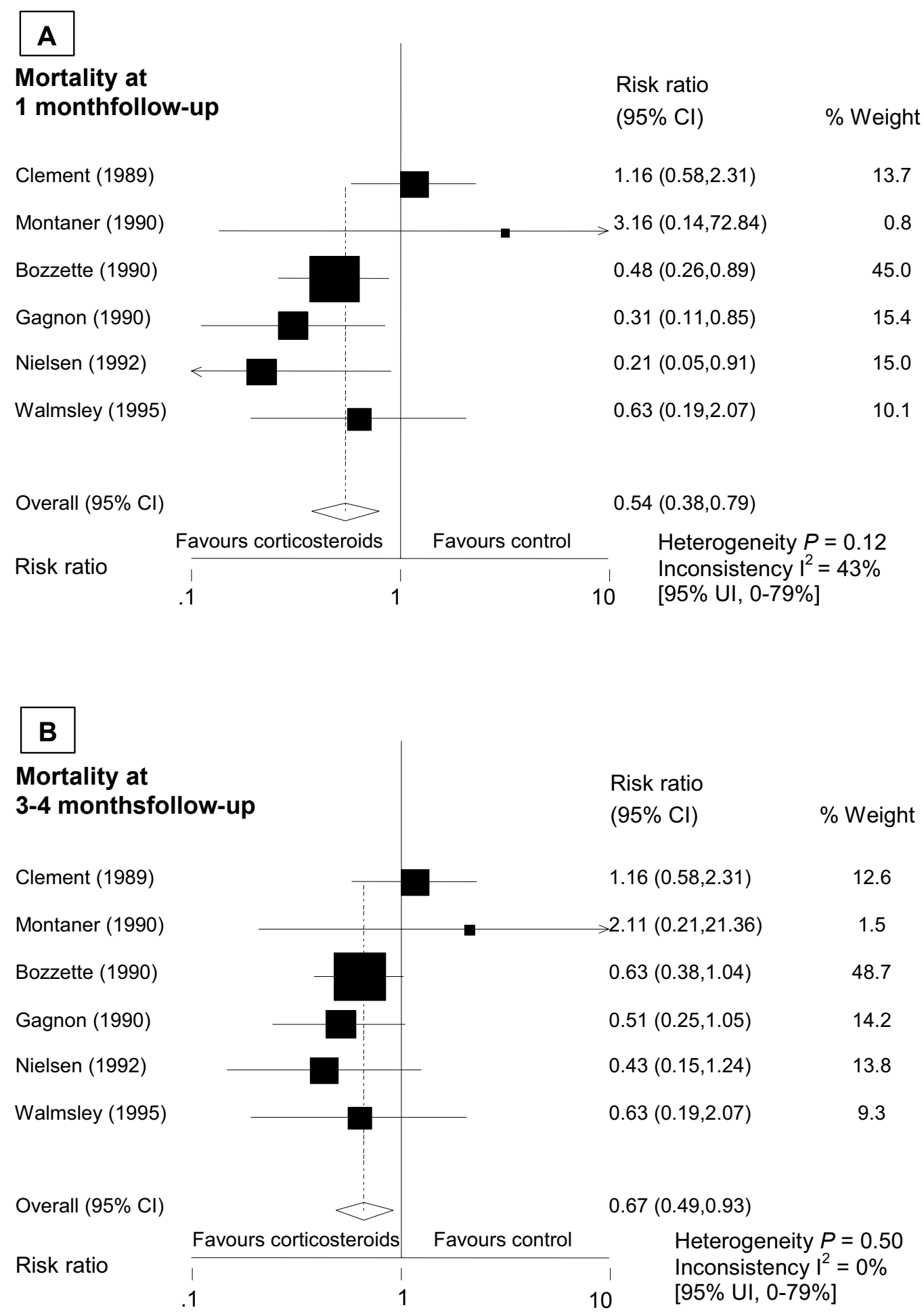

Figure 3

Summary estimates for overall mortality at I month (A) and 3-4 months (B) follow-up. The Cochran $Q$ test for heterogeneity. $\mathrm{I}^{2}$ as a measure of inconsistency (in percent). $\mathrm{Cl}$ indicates confidence interval; UI, uncertainty interval. 
early [11]. The main endpoint for benefit of adjunctive corticosteroid therapy was overall mortality. A secondary endpoint was the need for mechanical ventilation.

\section{Statistical analysis}

All analysis was according to the intent-to-treat principle. We pooled treatment effects across studies and calculated a weighted average risk ratio of overall mortality in the treatment and control groups by using a random effects model. We investigated the presence of publication bias by means of funnel plots [12]. We tested for heterogeneity with the Cochran Q test and measured inconsistency ( $\mathrm{I}^{2}$; the percentage of total variance across studies that is due to heterogeneity rather than chance) of treatment effects across studies $[13,14]$. We carried out sensitivity analyses to examine treatment effects according to quality components of trials, and if publication was as a peer-reviewed article or just in abstract form. Numbers needed to treat were calculated by multiplying the mean relative risk reduction with an initial mean baseline risk [15]. All statistical analyses were performed using Stata 8.2 (StataCorp, College Station, Tex).

\section{Results}

We identified 8 trials [6-9,16-19] that met our inclusion criteria (Figure 1). We excluded one trial [17] because it investigated only patients with mild hypoxemia and had a very short follow-up of only 3 days, and another trial [18] which turned out to be a subgroup analysis of a larger included trial [8] [see Additional file 1]. In total, there were 242 individuals in the intervention and 247 individuals in the control groups. The Funnel plot indicated no evidence for a publication bias (Figure 2). Characteristics of included trials are provided in Table 1.

\section{Overall mortality}

Risk ratios for overall mortality were significantly reduced for adjunctive corticoids at 1 month $(0.54 ; 95 \%$ CI, 0.38$0.79)$ and at 3-4 months $(0.67 ; 95 \%$ CI, 0.49-0.93) of follow-up (Figure 3 ). We found some evidence for heterogeneity among trials at 1 month (test of heterogeneity, $\mathrm{P}=$ $0.12 ; \mathrm{I}^{2}=43 \%$ [95\% uncertainty interval [UI], 0\%-78\%]) whereas at 3-4 months treatment effects looked more homogenous ( $\mathrm{P}=0.46 ; \mathrm{I}^{2}=0 \%$ [95\% UI, $\left.0 \%-75 \%\right]$. In a sensitivity analysis heterogeneity was considerably reduced when the analysis was limited to trials with early ( $<3$ days) adjunctive corticosteroids that were published in full, i.e. excluding Clement et al. [9] (summary risk ratio for mortality at 1 month: 0.45 (95\% CI, 0.29-0.70), heterogeneity $\mathrm{P}=0.49 ; \mathrm{I}^{2}=0 \%[95 \%$ UI, $\left.0 \%-79 \%]\right)$. In further sensitivity analyses for the mortality endpoint at 1 month summary risk ratios were 0.55 (95\% CI, 0.320.93 ) in trials that reported concealed allocation $[8,16,19], 0.74(95 \% \mathrm{CI}, 0.45-1.21)$ in trials reporting blinding of patients and care-givers $[7-9,19]$, and 0.64
(95\% CI, 0.42-0.98) in trials not prematurely halted $[9,16,19]$.

\section{Need for mechanical ventilation}

Reliable data on the need for mechanical ventilation was only available for the 3 largest trials $[6,16,19]$. Again, the risk ratio for this endpoint was largely reduced in the group with early adjunctive corticosteroids $(0.37 ; 95 \% \mathrm{CI}$, $0.20-0.70 ; \mathrm{P}=0.40 ; \mathrm{I}^{2}=0 \%$ [95\% UI, $\left.0 \%-90 \%\right]$ ).

\section{Discussion}

This systematic review of 6 randomised controlled trials in HIV-infected patients with PCP and substantial hypoxemia found a significant relative risk reduction of death for adjunctive corticosteroids of $46 \%$ at 1 month and of $33 \%$ at $3-4$ months. The average-weighted mean mortality in control groups of included trials at one month was $25 \%$. This initial mortality-rate of $25 \%$ can be assumed in settings where HAART is not available which is still the case for most developing countries [20]. In this situation we estimated that 9 ( $95 \%$ CI, 6-19) HIV-infected patients with PCP have to be treated early with adjunctive corticosteroids to prevent 1 death during the first month after PCP diagnosis. In Western countries, where HAART is widely available, the respective number to treat was estimated to be 22 (95\% CI, 16-48) patients assuming an initial mortality rate of $10 \%$ [21]. With regard to the need for mechanical ventilation the risk reduction for adjunctive corticosteroids was even greater in the investigated patient population, but the number of trials was small $(n=3)$.

Our study has several strengths and limitations. We conducted an extensive literature search to retrieve all eligible trials. However, formal testing for publication bias was not very powerful because of a relatively small number of included trials. Even with a symmetric looking funnel plot, such bias cannot be ruled out. Moreover, with a small number of included trials the uncertainty interval for the inconsistency among trials may not be very informative [13]. We focused mainly on mortality data that may be less prone to ascertainment bias, and we analysed the data according to the intent-to-treat principle to get more conservative estimates. Finally, the trials included in this meta-analysis used different corticosteroid regimen. So far, neither the dosing nor the length and tapering schedule of corticosteroids has been addressed adequately in randomised trials. In current recommendations [5] the corticosteroid schedule of the largest trial [16] was adapted.

There has been some concern among physicians treating patients with AIDS that further immunosuppression due to corticosteroid therapy could accelerate the onset of other HIV-related opportunistic complications [22,23]. However, with the exception of an increase in muco-cuta- 
neous herpes simplex infection episodes [16], adjunctive corticosteroids were not associated with an increase in opportunistic complications in any of the included trials. A large cohort study which used a standard 21-day tapering course of adjunctive corticosteroids found no difference in the risk of AIDS-related complications apart from an increase in esophageal candidiasis [24].

It is possible that adjunctive corticosteroids are also beneficial for HIV-infected patients with mild hypoxemia due to PCP [17]. However, in this situation the short term mortality is low and possible unfavourable effects of corticosteroids might outweigh the benefits. Moreover, corticosteroids might also be beneficial for non-HIV-infected patients with severe PCP [25], but evidence from randomised controlled trials is still lacking.

\section{Conclusion}

This meta-analysis confirmed and quantified the benefit of adjunctive corticosteroid therapy in HIV-infected patients with moderate-severe PCP. We estimated a relative risk reduction for overall mortality of $46 \%$ at 1 month and $33 \%$ at 3-4 months. We calculated numbers needed to treat of 9 patients for settings without HAART, and 22 patients with HAART available to prevent 1 death. Our results underline the conclusions of the early released consensus statement [4], and support current recommendations for the management of PCP in HIV-infected patients [5].

\section{Competing interests}

The author(s) declare that they have no competing interests.

\section{Authors' contributions}

$\mathrm{MB}$ and $\mathrm{HCB}$ conceived of the study and performed the literature search. $\mathrm{MB}, \mathrm{HCB}, \mathrm{RB}$ and $\mathrm{HF}$ checked eligibility and quality of trials, and extracted the necessary data. $\mathrm{MB}$ performed the statistical analyses and drafted the manuscript with the help of HCB, RB and HF. All authors read and approved the final version.

\section{Additional material}

\section{Additional File 1}

Table with characteristics of excluded trials and reasons for exclusion. Click here for file

[http://www.biomedcentral.com/content/supplementary/14712334-5-101-S1.doc]

\section{Acknowledgements}

We would like to thank M. Simcock for proofreading the manuscript.
There was no external funding for the study. H.C. Bucher and M. Briel are supported by Santésuisse and the Gottfried and Julia Bangerter-Rhyner Foundation, Switzerland. These institutions had no role in the study design, data collection, data analysis, data interpretation, writing and submission of the manuscript for publication.

\section{References}

I. Stringer JR, Beard CB, Miller RF, Wakefield AE: A new name (Pneumocystis jiroveci) for Pneumocystis from humans. Emerg Infect Dis 2002, 8:891-896.

2. Kaplan JE, Hanson D, Dworkin MS, Frederick T, Bertolli J, Lindegren $\mathrm{ML}$, Holmberg S, Jones JL: Epidemiology of human immunodeficiency virus-associated opportunistic infections in the United States in the era of highly active antiretroviral therapy. Clin Infect Dis 2000, 30 SuppI I:S5-I4.

3. Randall CJ, Yarnold PR, Schwartz DN, Weinstein RA, Bennett CL: Improvements in outcomes of acute respiratory failure for patients with human immunodeficiency virus-related Pneumocystis carinii pneumonia. Am J Respir Crit Care Med 2000, 162:393-398.

4. Consensus statement on the use of corticosteroids as adjunctive therapy for pneumocystis pneumonia in the acquired immunodeficiency syndrome. The National Institutes of Health-University of California Expert Panel for Corticosteroids as Adjunctive Therapy for Pneumocystis Pneumonia. N Engl J Med 1990, 323:1500-1504.

5. Benson CA, Kaplan JE, Masur H, Pau A, Holmes KK: Treating opportunistic infections among HIV-exposed and infected children: recommendations from CDC, the National Institutes of Health, and the Infectious Diseases Society of America. MMWR Recomm Rep 2004, 53: I-I I 2.

6. Nielsen TL, Eeftinck Schattenkerk JK, Jensen BN, Lundgren JD, Gerstoft J, van Steenwijk RP, Bentsen K, Frissen PH, Gaub J, Orholm M, Hansen J, Mathiesen L, Skinhoj P, Danner SA, Nielsen JO: Adjunctive corticosteroid therapy for Pneumocystis carinii pneumonia in AIDS: a randomized European multicenter open label study. J Acquir Immune Defic Syndr 1992, 5:726-73I.

7. Gagnon S, Boota AM, Fischl MA, Baier H, Kirksey OW, La Voie L: Corticosteroids as adjunctive therapy for severe Pneumocystis carinii pneumonia in the acquired immunodeficiency syndrome. A double-blind, placebo-controlled trial. $N$ EnglJ Med 1990, 323: | 444-1 450 .

8. Montaner JS, Lawson LM, Levitt N, Belzberg A, Schechter MT, Ruedy $\mathrm{J}$ : Corticosteroids prevent early deterioration in patients with moderately severe Pneumocystis carinii pneumonia and the acquired immunodeficiency syndrome (AIDS). Ann Intern Med 1990, I I 3: I 4-20.

9. Clement M, Edison R, Turner J, Montgomery B, Luce J, Feigal D, Hopewell P: Corticosteroids as adjunctive therapy in severe Pneumocystis carinii pneumonia: a prospective placebo-controlled trial. Am Rev Respir Dis 1989, 139:A250 (abstract).

10. Sistek CJ, Wordell CJ, Hauptman SP: Adjuvant corticosteroid therapy for Pneumocystis carinii pneumonia in AIDS patients. Ann Pharmacother 1992, 26: I I27-I I 33.

II. Juni $P$, Witschi $A$, Bloch R, Egger M: The hazards of scoring the quality of clinical trials for meta-analysis. JAMA 1999, 282: 1054-1060.

12. Sterne JA, Egger M, Smith GD: Systematic reviews in health care: Investigating and dealing with publication and other biases in meta-analysis. BMJ 200I, 323:I0I-I05.

13. Higgins JP, Thompson SG, Deeks JJ, Altman DG: Measuring inconsistency in meta-analyses. BMJ 2003, 327:557-560.

14. Higgins JP, Thompson SG: Quantifying heterogeneity in a metaanalysis. Stat Med 2002, 21:1539-1558.

15. Marx A, Bucher HC: Numbers needed to treat derived from meta-analysis: a word of caution. ACP J Club 2003, I38:A I I-AI2.

16. Bozzette SA, Sattler FR, Chiu J, Wu AW, Gluckstein D, Kemper C, Bartok A, Niosi J, Abramson I, Coffman J, Hughlett C, Loya R, Cassens B, Akil B, Meng T, Boylen CT, Nielsen D, Richman DD, Tilles JG, Leedom J, McCutchen JA: A controlled trial of early adjunctive treatment with corticosteroids for Pneumocystis carinii pneumonia in the acquired immunodeficiency syndrome. California Collaborative Treatment Group. N Engl J Med 1990, 323:145I-I 457 . 
17. Jeantils V, Nguyen G, Bacle F, Thomas M: Adjunctive treatment with corticosteroids for Pneumocystis carinii pneumonia in AIDS. Therapie 1993, 48:70-7I.

18. Montaner JS, Guillemi S, Quieffin J, Lawson L, Le T, O'Shaughnessy M, Ruedy J, Schechter MT: Oral corticosteroids in patients with mild Pneumocystis carinii pneumonia and the acquired immune deficiency syndrome (AIDS). Tuber Lung Dis 1993, 74:173-179.

19. Walmsley S, Levinton C, Brunton J, Muradali D, Rappaport D, Bast M, Spence D, Salit I: A multicenter randomized double-blind placebo-controlled trial of adjunctive corticosteroids in the treatment of Pneumocystis carinii pneumonia complicating the acquired immune deficiency syndrome. J Acquir Immune Defic Syndr Hum Retrovirol 1995, 8:348-357.

20. Fisk DT, Meshnick S, Kazanjian PH: Pneumocystis carinii pneumonia in patients in the developing world who have acquired immunodeficiency syndrome. Clin Infect Dis 2003, 36:70-78.

21. Sepkowitz KA: Opportunistic infections in patients with and patients without Acquired Immunodeficiency Syndrome. Clin Infect Dis 2002, 34:1098-1 107.

22. Lambertus MW, Goetz MB, Murthy AR, Mathisen GE: Complications of corticosteroid therapy in patients with the acquired immunodeficiency syndrome and Pneumocystis carinii pneumonia. Chest 1990, 98:38-43.

23. Nelson MR, Erskine D, Hawkins DA, Gazzard BG: Treatment with corticosteroids--a risk factor for the development of clinical cytomegalovirus disease in AIDS. AIDS 1993, 7:375-378.

24. Gallant JE, Chaisson RE, Moore RD: The effect of adjunctive corticosteroids for the treatment of Pneumocystis carinii pneumonia on mortality and subsequent complications. Chest 1998, I | 4: I258-1263.

25. Pareja JG, Garland R, Koziel H: Use of adjunctive corticosteroids in severe adult non-HIV Pneumocystis carinii pneumonia. Chest 1998, I13:1215-1224.

\section{Pre-publication history}

The pre-publication history for this paper can be accessed here:

http://www.biomedcentral.com/1471-2334/5/101/pre

pub

Publish with Biomed Central and every scientist can read your work free of charge

"BioMed Central will be the most significant development for disseminating the results of biomedical research in our lifetime. "

Sir Paul Nurse, Cancer Research UK

Your research papers will be:

- available free of charge to the entire biomedical community

- peer reviewed and published immediately upon acceptance

- cited in PubMed and archived on PubMed Central

- yours - you keep the copyright 